Est Ag 55 (2017) 173-205

\title{
La caracterización de Jesús en las notas del narrador y su papel en el relato del cuarto evangelio
}

\author{
José Manuel Hernández CARraCEdo
}

RESUMEN: El presente artículo expone las bases de un futuro estudio que analiza cómo el narrador caracteriza a Jesús en sus "notas" y cómo éstas ayudan a comprender adecuadamente la identidad de Jesús y sirven de guía para el lector en la lectura del relato.

Para ello se ofrece una breve exposición de la historia de la investigación que se ha ocupado de los comentarios del narrador y se presenta, recurriendo a la teoría de la Polifonía y a la lingüística moderna, una metodología que permite definir e identificar los comentarios del narrador como notas dirigidas directamente al lector. El artículo se finaliza con un ejemplo de cómo estas notas ayudan a la caracterización de Jesús a lo largo del relato.

Palabras Claves: Análisis Narrativo. Cristología. Enunciado Parentético. Evangelio de Juan. Identidad Narrativa. Narrador. Prólogo del evangelio según san Juan.

ABSTRACT: The present article explains the basis for a further study that makes an analysis of the characterization of Jesus made by the narrator in his "notes" and how they help to correctly understand the identity of Jesus and how they help as a guide for the reader in the reading of the story.

To that end, we provide a brief exposition of the history of the research related to the narrator commentaries and, taking into account the polyphonic theory of enunciation and the modern linguistics, we show a methodology that allows for the definition and identification of the narrator commentaries as notes addressed directly to the reader.

The article concludes with an example of how these notes help in the characterization of Jesus across the story. 
Keywords: Narrative Analysis, Christology, Parenthetical Statements, Gospel of John, Narrative Identity, Narrator, Prologue to the Gospel according to John.

\section{INTRODUCCIÓN}

Dos de los rasgos más característicos del cuarto evangelio son la existencia de comentarios del autor a lo largo del relato y su interés cristológico. Estas dos características, una literaria y otra cristológica, se relacionan entre sí. La primera sirve de cauce a la segunda: el acceso a la identidad de Jesús se alcanza por medio de la narración y su estrategia narrativa, dentro de la cual destaca el papel del narrador ${ }^{1}$. Este artículo refleja el comienzo de un trabajo de investigación en el que se estudiará cómo las notas del narrador caracterizan a Jesús y contribuyen a crear su identidad narrativa a lo largo de la trama del evangelio ${ }^{2}$.

Tanto la identidad del Jesús juánico como la peculiaridad literaria del cuarto evangelio ya han sido objetos de estudio a lo largo de la historia de la investigación. La novedad de este estudio radica en la unión de los dos aspectos: el de la forma literaria, la nota del narrador (enunciado) y la caracterización de Jesús (contenido). Desarrollaré está contribución -en homenaje y recuerdo agradecido al profesor Senén Vidal- comenzando con una breve exposición de los trabajos de investigación más significativos, que se refieren a las notas del narrador en el evangelio de Juan. En una segunda parte, expondré el planteamiento metodológico adoptado en este estudio para definir e identificar las notas del narrador en el relato, y por último, a modo de ejemplo, analizaré las primeras notas cristológicas que el narrador inserta en su relato y son cruciales para la comprensión de todo el evangelio (Jn 1,17-18).

\section{UN BREVE ESBOZO DE LA HISTORIA DE LA INVESTIGACIÓN}

Con la sola lectura de las ediciones críticas del Nuevo Testamento se constata la existencia de enunciados entre paréntesis o entrecomillados.

1 Zumstein, Jean, "La rédaction finale de l'evangile selon Jean (Á l'exemple du chapitre 21)", en KAestli, Jean Daniel - Poffet, Jean Michel - Zumstein, Jean (eds.), La communauté Johannique et son histoire (=Le monde de la Bible 20), Labor e Fides, Geneve 1990, 222.

${ }^{2}$ La terminología para referirse a estos comentarios entre los estudiosos es muy diversa. En nuestro estudio nos referiremos a ellos como "notas" según su definición en el Diccionario de la Real Academia. 
Estos signos de puntuación no son justificados por los editores y difieren de unas ediciones a otras ${ }^{3}$. Su presencia, incluso en las traducciones modernas ${ }^{4}$, nos permiten preguntarnos: ¿Qué enunciados son realmente notas?

Las gramáticas del griego del Nuevo Testamento señalan la gran subjetividad a la hora de señalar esos paréntesis y buscan una definición para identificarlos. En general, definen "paréntesis" como una frase o enunciado independiente gramaticalmente de los elementos entre los que se insertan, aunque conserve con ellos una relación lógica.

Ya desde el siglo XVIII los estudiosos del cuarto evangelio consideran las notas explicativas del relato como uno de los rasgos más característicos del estilo del evangelista. Esas notas eran prueba de la veracidad e historicidad del relato. En ellas el autor explicaba sus propias palabras y aclaraba su intención a los lectores 5 .

Los estudios de la crítica literaria también han contemplado las notas del evangelio como una característica particular de esta obra. Las notas y los comentarios del autor pasaron a ser la clave para identificar las distintas fuentes del evangelio, diferenciar las etapas de la redacción y detectar la presencia de diferentes autores en ese proceso. Pese a sus esfuerzos, no se ha logrado atribuir de forma unánime el origen de estos comentarios a un estadio concreto de la composición del evangelio y menos aún, a un autor particular, ya sea éste el evangelista, el redactor o el editor.

Es Merrill C. Tenney, en su artículo "The Footnotes of John's Gospel”, el primero en constatar la existencia de un material explicativo que no está involucrado en el progreso narrativo del evangelio, pero que no es irrelevante para interpretar el relato y encontrar su significado adecuado, por lo cual merece una atención especial a la hora de estudiar el evangelio ${ }^{7}$. A estos enunciados explicativos los denomina "nota a pie de página" (Footnotes): en ellas, el autor explica la causa o el motivo de una acción que aparece en el relato. Tenney señala la dificultad de delimitar e identificar estas notas, ya que algunas de ellas están integradas en la trama narrativa, y por

\footnotetext{
3 VAN BELLE, Gilbert, Les parenthèses dans l'evangile de Jean. Aperçu Historique et classification. Texte grec de Jean (=Studiorum Novi Testamenti Auxilia XI), Leuven University Press, Leuven 1985, 3-9.

${ }^{4}$ Sagrada Biblia. Versión oficial de la Conferencia Episcopal española, Madrid 2011. En los primeros capítulos de esta versión aparecen paréntesis en Jn 1,38.41.42; 2,9; 4,2.9 que son claramente notas del narrador. Pero no aparecen los paréntesis en otros versículos donde aparecen notas del narrador con la misma claridad, como por ejemplo Jn 2,21.

${ }^{5}$ VAN BeLLE, Les parenthèses, 17-26.

6 Tenney, Merrill C., "The Footnotes of John's Gospel”, en Bibliotecha Sacra 117 (1960), 350-364.

7 TenNEY, “The Footnotes”, 350.
} 
lo tanto no serían "notas a pie de página". Estos enunciados aparecen a lo largo de todo el evangelio, exceptuando Jn 13,31-17,26, y juegan un papel fundamental en su estructura. Por su variedad y poca sistematicidad dan la impresión de ser notas orales que se introdujeron en la lectura pública del relato y que quedaron fijadas por escrito. De todo ello, deduce que el autor del evangelio habría tenido una gran proximidad con Jesús, y sus "notas a pie de página" serían una interpretación "anotada" de la persona y de la obra de Jesús ${ }^{8}$. Al final de su artículo presenta una clasificación de las notas que él ha encontrado, pero no ofrece ni una definición, ni un criterio de identificación.

Diecinueve años después, John O'Rourke retoma el trabajo de Tenney en su artículo "Asides in the Gospel of John" en el que adopta la misma clasificación de las notas pero corrige su catalogación y distribución. Por su contenido, una misma nota puede clasificarse en distintas categorías a la vez. O'Rourke expresa la imposibilidad de discernir qué notas se encontrarían en las fuentes del autor y cuáles se deben a su propia mano, por lo que no son un criterio útil para la crítica literaria del evangelio. Es significativa su aportación sobre la flexibilidad de las notas a la hora de ser catalogadas.

A partir de los años ochenta del siglo pasado, aparecen los primeros estudios narrativos en el campo bíblico. Para la crítica narrativa el texto es un vehículo de significados y de estrategias que buscan suscitar determinadas respuestas en el lector. La interpretación de los relatos tiene que tener en cuenta la lengua, el tono y la estructura de la obra, prestando una especial atención al punto de vista del narrador y a sus comentarios, tanto explícitos como implícitos, en la evolución de la trama ${ }^{10}$. En lo que se refiere al cuarto evangelio, el trabajo referencial es el de R.A. Culpepper ${ }^{11}$. En este estudio se presta una especial atención a la figura del narrador. Un narrador omnisciente e intrusivo que ofrece al lector toda la información necesaria para que comprenda correctamente el relato. Para Culpepper las

8 TEnNEY, "The Footnotes", 362-363. Aunque el autor no se separa de una interpretación "histórica", su conclusión ya apunta a lo que en un análisis narrativo llamaremos identidad narrativa.

9 O'Rourke, John, “Asides in the Gospel of John”, en Novum Testamentum 21 (1979), 210-219.

10 CulPePper, R. Alan, “La narratologie et l'evangile de Jean” en KAESTLI, Jean.Daniel - Poffet, Jean Michel - Zumstein, Jean (eds.), La communauté Johannique et son histoire (=Le monde de la Bible 20), Labor et Fides, Geneve 1990, 97-104.

11 Culpepeer, R. Alan., Anatomy of the Fourth Gospel. A study in Literary Design, Fortress Press, Philadelfia 1983; CulPePEer, R. Alan., "The Narrator in the Fourth Gospel: Intertextual Relantionships”, en Richards, K.H. (ed.), SBL Seminar Papers Series 20, Chico, 1982, 81-96. 
intervenciones del narrador no son glosas, sino partes fundamentales del texto que se distribuyen a lo largo de la trama, introduciendo a los lectores en su sistema de valores y de ideas. Sus comentarios interpretativos tienen la función de vehicular el desarrollo argumental del relato. De esta manera, el narrador conduciendo al lector por la sucesión de los acontecimientos del evangelio aparece como un intérprete fiable de lo que la persona de Jesús, su entrega, su muerte y glorificación significan ${ }^{12}$. Su voz no sólo cuenta la historia, sino que al contarla la interpreta. Por lo tanto, el enfoque narrativo pone en evidencia la importancia de la figura del narrador y de sus comentarios, haciendo pertinente un estudio de los mismos, más allá de los que hasta ese momento habían sido realizados.

En 1985 aparece una amplia monografía publicada por G. Van Belle dedicada a los paréntesis en el evangelio de Juan: Les parenthèses dans l'evangile de Jean. Aperçu Historique et classification. Texte grec de Jean. En ella se presenta una minuciosa historia de la investigación y distintas clasificaciones de los paréntesis juánicos realizadas hasta aquel momento. El autor aporta sus propias conclusiones en las que defiende que los paréntesis son una verdadera particularidad del cuarto evangelio y merecen ser tenidos en cuenta en el estudio del conjunto de la obra juánica. Para él los paréntesis del evangelio responden a la lógica de la comunicación humana, en la que un autor interrumpe su exposición para comentar, repetir o adelantar su pensamiento; mantienen un estilo constante y homogéneo con el resto del relato y en ellos se reflejan los principales temas teológicos del mismo. Gracias a los comentarios del narrador el autor construye su estrategia narrativa, por la que se desarrolla la trama del evangelio y sostienen su estructura, a la vez que guían en la lectura13.

En el año 1994 Tom Thatcher en su artículo A new Look at Asides in the Fourth Gospel14 recupera la intuición de Tenney y de O'Rourke señalando la importancia de las notas para la comprensión de la estructura y la interpretación del evangelio. Teniendo en cuenta las aportaciones de la crítica narrativa, busca una definición y una categorización más precisa de los paréntesis del narrador. Así pues, los define como frases directas que se dirigen al lector comentando e interpretando eventos observables en el relato o revelando una información que subyace por debajo de la acción narrada. Estos comentarios son siempre del autor y no hacen avanzar el

12 CUlPePper, Anatomy, 36.

13 VAN BELLE, Les parenthèses, 206-210.

14 Thatcher, Tom, "A New Look at Asides in The Fourth Gospel”, en Bibliotheca Sacra 151 (1994), 428-439. 
argumento, sino que su objetivo es guiar la interpretación del lector y su respuesta; por lo que su función es sobre todo retórica. Lo más relevante del artículo es el esfuerzo por encontrar una definición que permita identificar los paréntesis en el relato, así como subrayar su importancia retórica.

Recientemente Jean Zumstein ha prestado una especial atención al papel del narrador en el relato juánico y también a sus comentarios explícitos, que sitúa dentro del fenómeno más amplio de la intratextualidad y la intertextualidad ${ }^{15}$. El autor observa que el cuarto evangelio es un relato que se interpreta a sí mismo a través de relaciones de sentido intratextuales mediante distintos procedimientos literarios, entre los que destacan los comentarios del narrador. Zumstein esboza una definición del comentario del narrador: es aquel enunciado que interrumpe el desarrollo del relato para tomar posición a nivel metalingüístico sobre aquello que comenta ${ }^{16}$. Los comentarios tienen la función de profundizar la reflexión teológica del texto comentado; no son una mera yuxtaposición de dos enunciados, sino que el primer texto es retomado de una forma creativa por el segundo, de forma que el sentido inicial es profundizado y alargado. Los comentarios del narrador forman parte de la estrategia narrativa del autor, que busca que el lector alcance la verdadera identidad de Cristo como el Hijo, y de esta forma, revitalice y reestructure su $\mathrm{fe}^{17}$.

A modo de conclusión podemos decir que el estudio de los comentarios del narrador, en el cuarto evangelio, ha sido una constante a lo largo de la historia de la investigación. Una de sus grandes aportaciones ha sido su papel en el estudio de la compleja formación del evangelio. El enfoque narrativo ha permitido avanzar en el estudio sobre la función y el significado de los comentarios del narrador. Al pertenecer a la voz del narrador y a la estrategia narrativa del relato, tienen gran importancia a la hora de interpretar el evangelio. El lector encuentra en ellos un primer comentario al evangelio y una interpretación "anotada" de los personajes, principalmente de Jesús. A la vez se ha constatado, a lo largo de la investigación, la gran dificultad para encontrar una definición adecuada de estos enunciados, así como un criterio para identificarlos.

15 ZuMSTEIN, Jean, "Procesos de relectura y recepción de la Escritura en el cuarto evangelio", en Estudios Bíblicos 70 (2012) 37-54.

16 ZuMSTEIN, "Procesos", 44-45.

17 Zumstein, Jean, "L'evangile Johannique: une stratègie du croire", en Recherches de Science Religieuse 77 (1989) 217-232; ZuMSTEIN, "La rédaction", 222. 


\section{LA METODOLOGÍA}

El análisis narrativo parte de la premisa de que todo relato está compuesto con el objetivo de producir un efecto en el lector. Por este motivo, trata de localizar en el texto las señales que marcan y orientan el recorrido de la lectura preguntándose qué función asumen los detalles del texto, en qué orden aparecen, y qué información dan al lector, ya que estos elementos constituyen la estrategia narrativa desplegada por el autor, de la que es portavoz el narrador.

Por lo cual, para realizar nuestro estudio debemos encontrar una herramienta que permita definir e identificar, de la forma más objetiva posible, aquellas intervenciones del narrador que pueden ser consideradas como notas. Con este fin recurriremos a la teoría lingüística moderna y más concretamente a la teoría de la enunciación. También necesitamos conocer cómo un relato caracteriza a un personaje y qué fin persigue dicha caracterización.

\section{La enunciación del relato: la teoría de la polifonía}

El método narrativo estudia tanto el contenido del relato como su enunciación, es decir "cómo" es contado el relato: "Escribir sobre algo es, en primer lugar, hacer que exista... pero también que exista de una determinada manera"18. Esto nos obliga a estudiar su retórica narrativa, el dispositivo mediante el cual un narrador enuncia la historia ${ }^{19}$.

$\mathrm{El}$ autor utiliza distintos mecanismos lingüísticos para transmitir su punto de vista ${ }^{20}$, entre ellos destaca el de la polifonía. La teoría polifónica de la enunciación considera que en gran parte de los enunciados, pueden rastrearse voces y puntos de vista diferentes que se esconden tras las palabras del texto. Las voces del relato tienen una finalidad persuasiva: intentan convencer y persuadir al lector de su propio criterio y visión de las cosas, para dirigirle hacia determinadas conclusiones ${ }^{21}$.

\footnotetext{
18 ESCRIBANO, Asunción, Las voces del texto como recurso persuasivo (=Cuadernos de Lengua Española 106), Arcos Libro, Madrid 2009, 12.

19 Marguerat-Bourquin, Cómo leer, 39.

${ }^{20}$ ESCRIBANO, Las voces, 8-10.

${ }^{21}$ Escribano, Las voces , 47. Esto es lo que busca el evangelista: persuadir a sus lectores para que crean en Jesús (cf. Jn 20,31). La profesora Asunción Escribano señala los siguientes recursos lingüísticos, que se pueden rastrear en el cuarto evangelio: la cita de autoridad (Jn 7,37-38;...), el tópico de la mayoría (Jn 8,33;...), la diafonía (Jn 8,54;...), la negación polémica $(\mathrm{Jn} 18,36 ; \ldots)$, la ironía $(\mathrm{Jn} 3,10 ; \ldots)$.
} 
La teoría de la enunciación permite distinguir las distintas voces que aparecen en el relato: la del hablante, la del locutor y la de los enunciadores $^{22}$. "El hablante" es el ser empírico que tiene su campo de acción en el mundo, es decir, el autor real de la narración. "El locutor" es el ser del discurso que aparece en los textos y que se puede desdoblar en dos: "el locutor como tal", responsable de la enunciación (el narrador del relato), y el "locutor como ser en el mundo", ser del discurso al que se le atribuyen propiedades particulares como un ser completo. "Los enunciadores" son los distintos puntos de vista y actitudes que el locutor introduce en el texto.

La diferenciación de las voces del relato nos permiten marcar un primer criterio de identificación de las notas del narrador: son los enunciados que pertenecen a la voz del "locutor como tal", al narrador. Varios autores descubren un paréntesis en Jn 3,16-21, ya sean todos los versículos o sólo algunos 23 . Según nuestro criterio estos versículos no son notas del narrador porque en todos, tal y como aparecen en el relato, se escucha la voz de Jesús 24 .

Pero este criterio no basta para identificarlas, ya que el locutor-narrador puede hacer oír su propia voz de distintas maneras. Por lo cual consideraremos notas aquellos enunciados en los que el locutor aparece como enunciador de su relato, es decir, aquellos enunciados en los que el narrador aparece desdoblado presentándose en dos momentos distintos: en uno como constructor del texto y en el otro como el que lo aclara, comenta, completa o justifica.

La voz del narrador en Jn 1,35-39 aparece de maneras diferentes. Principalmente se presenta como constructor del hilo narrativo, en su papel de "locutor como tal". Pero también se presenta como enunciador de su relato en Jn 1,38 traduciendo para el lector el término "Rabbí"; igualmente en Jn 1,39, la voz del narrador aparece como enunciador de su relato, al informar al lector de la hora en la que ocurrió el primer encuentro entre Jesús y sus primeros dos discípulos, una información que no se encuentra dentro del hilo narrativo del episodio. También encontramos comentarios

22 EsCRIBANO, Las voces, 47.

23 VAN BELLE, Les parenthèses, 69.

${ }^{24}$ Con esta afirmación no decimos que aquí no aparezca una tradición introducida por el autor en momentos distintos de la composición del evangelio sino que, aun siendo así, el autor la ha introducido en boca de Jesús por lo cual no se enuncia como un comentario o nota del narrador, que es el fin específico de nuestro estudio. Senén Vidal considera Jn 3,12-21 una ampliación del discurso de Jesús introducido por el autor del "evangelio transformado" (VIDAL, Senén, Los escritos originales de la comunidad del discípulo "amigo" de Jesús (=Biblioteca de estudios Bíblicos 93), Sígueme, Salamanca 1997). Nuestro estudio no pone en tela de juicio tal afirmación. 
del narrador en Jn 1,36. 38 en los que el narrador comenta su propio discurso informando al lector de distintas circunstancias en las que se desarrolla la escena: Juan Bautista "Fijándose en Jesús que pasaba..." (Jn 1,36) y Jesús "al ver que le seguían" (Jn 1,39). ¿Son todos estos comentarios notas del narrador? Para resolver esta pregunta debemos recurrir a la teoría de la enunciación.

\section{El enunciado parentético}

La teoría de la enunciación ha estudiado la existencia de los denominados enunciados parentéticos, recurso específico muy cercano al fenómeno de la polifonía. Es un medio ideal por el cual el narrador se desdobla en el texto y apela directamente al lector ${ }^{25}$. Los rasgos que nos permiten distinguirlos de otros recursos lingüísticos son los siguientes: su constitución fonológica termina en semicadencia; persiguen una intención comunicativa específica, que parece no estar en el plan originario del texto; interrumpen la estructura sintáctica y la linealidad discursiva; poseen una intención o función macro estructural: completar una información añadiendo un dato, explicando o precisando una información no conocida, mostrando un antecedente necesario o focalizando un elemento determinado ${ }^{26}$.

Estas características son las que utilizaremos para identificar formalmente los enunciados que aparezcan verdaderamente como notas del narrador, diferenciándolos de otros recursos con una función y una forma similar. El criterio esencial de esta definición no es la entonación, ni la finalidad o la función del enunciado, sino la ausencia de relación oracional entre los segmentos enunciativos, entre el comentario y lo comentado; ya que existen otras estructuras enunciativas que poseen la misma característica de entonación, la misma finalidad y desempeñan la misma función, como son el inciso, la aposición y el estilo directo en un relato.

$\mathrm{El}$ inciso es una estructura entonativa que aparece entre pausas, separada de la oración, como marginal, que modifica a la oración en su totalidad o en un sintagma exclusivamente. Esta estructura incidental conlleva siempre una especie de predicación, innegable cuando aparece un participio, infinitivo y gerundio; por lo que son complementos que tienen una función predicativa o circunstancial y aparecen entre pausas. Al existir una rela-

25 Fuentes, Catalina, La organización informativa del texto (=Cuadernos de Lengua Española 61), Arcos Libro, Madrid, 1999, 9.

26 Ibid., 172. 
ción sintáctica entre los dos enunciados no son comentarios parentéticos, por lo que no las consideramos notas explicativas ${ }^{27}$. Esto es lo que ocurre en Jn 1,36.38 en los que el narrador realiza un inciso, sin romper la línea discursiva, para comentar que el Bautista ha visto a Jesús, y que Jesús se ha dado cuenta de que los dos hombres le siguen. Son comentarios del narrador pero no son notas.

La aposición es una relación de equifuncionalidad entre dos elementos, que funcionan como sujeto, objeto directo, circunstancial..., de un verbo dentro de la misma oración. Aunque posea un contenido explicativo no tiene un carácter parentético, por lo que tampoco lo consideramos nota explicativa del narrador ${ }^{28}$.

El estilo directo de un relato sólo se puede considerar como un enunciado parentético cuando el enunciado marco o marginal aparece intercalado en el otro enunciado o al final del mismo ${ }^{29}$. Ejemplo de estos enunciados aparecen en los textos proféticos con la expresión "oráculo del Señor" colocadas tras las palabras del profeta (por ejemplo Jer 1,8.15.19). Por lo tanto no consideramos notas las expresiones del narrador en las que introduce los discursos de los personajes "dijo Jesús a ellos..." (Jn 1,38).

De la misma manera, tampoco podemos considerar como enunciados parentéticos las traducciones de los términos que introduce el narrador en su relato, ya que se presentan relacionados por un complemento de relativo. Por lo tanto Jn 1,38 tampoco se puede considerar como una nota del narrador.

De los ejemplos citados en Jn 1,35-39 sólo Jn 1,39 se puede considerar una verdadera nota del narrador, ¿pero de qué tipo? El enunciado parentético puede adoptar distintas formas: aclaraciones en un estilo directo, comentarios modales, digresiones informativas o argumentativas ${ }^{30}$.

El comentario modal es una aclaración sobre la enunciación ya sea para mostrar la actitud del locutor sobre lo dicho, o ya sea para indicar a su auditorio cómo debe ser entendido lo dicho. Son indicadores pragmáticos que llaman la atención del oyente. Funcionan como un signo que guía hacia una apreciación correcta de la afirmación. Añaden una precisión, una aclaración que precisa lo anterior. Aunque no es la información principal, es pertinente y necesaria para entender lo comunicado, resaltando lo dicho. Ayudan a comprender y aprehender lo que se dice más que formar parte

\footnotetext{
27 Ibid., 138-146.

28 Ibid., 147.

29 Ibid., 162.

30 Fuentes, Catalina, "Lo oral en lo escrito: los enunciados parentéticos", en Moenia, 5 (1999) 233-235.
} 
de lo que se dice. Entran así en el campo de lo parentético como una información marginal, destacada, sin conexión sintáctica con lo anterior y pertenece al nivel textual ${ }^{31}$. Ejemplos de comentarios modales encontramos en la voz de Jesús en el libro del Apocalipsis (Ap 2,7a.11.17.29; 3,6.13.22), en el mismo libro el narrador introduce una nota modal en Ap 13,18. En el evangelio de Juan podemos considerar como comentarios modales las intervenciones en las que el narrador se refiere al Discípulo Amado y a su testimonio fiable (Jn 19,35; 21,24).

La digresión es un añadido que se ofrece como un detalle relevante, focalizado, desde el punto de vista del narrador, que se introduce en cualquier punto del enunciado, apareciendo como algo que no estaba en su plan discursivo originario. Suele ser información no conocida o un dato que es necesario argumentativamente en ese lugar del texto para su correcta interpretación. No sólo comenta, sino que también añade algo nuevo en el discurso, por lo que afecta principalmente a la organización informativa del texto $^{32}$. Los ejemplos de digresiones son numerosos en el cuarto evangelio. Jn 1,39 es claramente uno en el que el narrador aporta un dato nuevo: la hora en la que se produjo el encuentro entre Jesús y sus discípulos. Basten otros dos ejemplos para mostrar su frecuencia y variedad. En Jn 2,17 el narrador introduce una nota donde informa del pensamiento de los discípulos de Jesús, que hasta ahora no habían aparecido en la escena. Su contenido añade algo nuevo al relato, pues adelanta implícitamente el destino de Jesús: "será devorado". También podemos considerar una digresión la nota final que cierra el capítulo segundo (Jn 2,22), en la que el narrador anticipa que Jesús ha muerto y resucitado y que tras ese acontecimiento los discípulos creerán en sus palabras y en las Escrituras, entablando así una nueva relación con él.

El enunciado parentético forma, junto con el enunciado al que comenta, una construcción sintáctica llamada estructura parentética. En ella dos enunciados se insertan el uno en el otro y presentan las siguientes características:

- Posee una especial constitución fonológica, el segmento precedente y el parentético terminan en semicadencia.

- Tiene la intención comunicativa de aparecer como un contenido elaborado en el momento de la comunicación, que no estaba en el plan originario del texto.

\footnotetext{
${ }^{31}$ FuENTES, “Estructuras", 151-155.168-169.

32 Ibid., 155-158.169.
} 
- Entre los dos enunciados se interrumpe la estructura sintáctica y la linealidad discursiva.

- Los enunciados pueden tener diferente modalidad ${ }^{33}$.

- La estructura parentética es un rasgo de oralización que proporciona una frescura y espontaneidad al texto, propia del lenguaje oral. El autor recrea el lenguaje oral en el lenguaje escrito para acercar el texto a un registro coloquial, directo, cercano al lector ${ }^{34}$.

El enunciado parentético cumple principalmente funciones enunciativas, modales o dictales. Son estas últimas las más relevantes para nuestro estudio, ya que, cuando cumplen esta función, añaden una información o realizan una justificación argumentativa. Esto hace que, a la hora de estudiar las notas del cuarto evangelio, debamos tener en cuenta no sólo la nota en sí, sino el enunciado al que comenta con el que forma una estructura parantética. Por ejemplo, la nota de Jn 2,24-25 solo puede comprenderse si la estudiamos en relación con Jn 2,23, donde el narrador informa de la fe en Jesús de los que han visto sus signos, pero el narrador comenta en 24-25 la actitud contraria, Jesús no se fía de ellos porque los conoce sobrenaturalmente, sin necesidad de un testimonio.

La disposición entonativa del enunciado parentético, dentro de la estructura, muestra la intencionalidad del hablante de presentarlo como información de segundo plano y como comentario de lo previo ${ }^{35}$. Son comentarios que hace el hablante sobre su propio discurso, interpretándolo a la vez que lo emite. Aparece como una información adicional, no pretendida, y por ello debería ser secundaria, pero al interrumpir una secuencia sintáctica queda focalizada ${ }^{36}$. Muestran una actitud reflexiva, muy cercana a la actividad reformulativa ${ }^{37}$.

Este concepto de enunciado parentético y estructura parentética nos dan la pauta para identificar y seleccionar los versículos que cumplen estas

33 FuENTES, "Lo oral" 231-232.

34 Ibid., 239. No debemos olvidar que Tenney ya señaló esta característica para sus notas a pie de página TENNEY, "The Footnotes", 350-364. Este rasgo nos permite relacionar nuestras notas con el proceso de transmisión oral del propio evangelio. Ver GuiJARro, Santiago, Los cuatro evangelios (=Biblioteca de Estudios Bíblicos 124), Sígueme, Salamanca 2010, 103-160.

35 Fuentes, Catalina, "Parentéticos, 'hedging' y sintaxis del enunciado", en Clac 55 (2013) 61-94, 82.

36 FUENTES, "Lo oral”, 231.

37 Esta teoría del enunciado parentético es muy similar al planteamiento que J. Zumstein adopta, desde la intratextualidad, a la hora de comprender y definir los comentarios del narrador, como hemos visto en la sección anterior. 
condiciones y que debemos contemplar para la caracterización de Jesús por parte del narrador a través de sus intervenciones directas y los enunciados previos que comenta.

Partiendo de estas aportaciones podemos definir las notas del narrador como: el enunciado que interrumpe la línea del discurso narrativo y la relación sintáctica, en el que el narrador aparece como comentador de su propio discurso completando una información, ya sea aclarándola, comentándola, especificándola o añadiendo un dato que permite al lector interpretar adecuadamente la información recibida y que posee una función macro estructural.

Por su marginalidad y finalidad, el material parentético que aparece en la voz del narrador adquiere características paratextuales. Aparecen muy cercanas a la función de las notas a pie de página que encontramos en los textos actuales o las notas marginales de los antiguos manuscritos ${ }^{38}$. Jean Zumstein utiliza la categoría de paratexto para estudiar la especificidad del prólogo (Jn 1,1-18) y el epílogo (Jn 21) del relato juánico. El paratexto es un conjunto de signos que presentan, encuadran, aíslan, introducen, interrumpen o cierran un texto determinado. Generalmente ejerce una función de acompañamiento de otro texto, expresando siempre una toma de postura en relación a él ${ }^{39}$. Las notas a pie de página responden, disienten, corrigen, aprueban, amplían, ubican la información que recoge el texto, pues siempre se refieren a un segmento del mismo, suelen contener información accesoria o que aun siendo importante, obstaculizaría la lectura porque interrumpe la continuidad del discurso. Por su naturaleza está en continuidad y homogeneidad con otros paratextos como el prólogo y el prefacio, de los que solo les distingue su carácter local ${ }^{40}$. Si se acepta esta caracterización es más fácil clasificar y clarificar los distintos tipos de comentarios del narrador dentro del evangelio. Zumstein clasifica como glosas comentarios de naturaleza tan distinta como Jn 4,2.44 (notas del narrador) y Jn 5,28-29; 6,39 (palabras de Jesús) ${ }^{41}$. Con nuestro criterio podríamos clasificar las notas del narrador como paratextos junto al prólogo y al epílogo, lo que nos ayudaría a distinguir los distintos procesos de intratextualidad dentro del relato. Si esto es así, de la misma forma que el prólogo y el epílogo del evan-

\footnotetext{
38 Una vez más la intuición de Tenney de denominar "Footnotes" a estos comentarios aparece reveladora y acertada.

39 ZuMsteIN, Jean, "Le processus de relecture dans la littérature Johannique" en Etudes Théologiques \& Religieuses 73 (1998) 161-176, 167.

40 Alvarado, Maite, Paratexto (=Enciclopedia Semiológica), Eudeba, Buenos Aires

41 ZuMSTEIN, “Le processus", 167-174.
} 2006, 64. 
gelio es importante para su interpretación, también lo son las notas del narrador.

Estas aportaciones de la teoría lingüística de la enunciación, a la vez que nos han proporcionado la herramienta para identificar las notas del cuarto evangelio, confirman la intuición de que este material parentético es relevante para la interpretación de la obra, ya que es un material con un rendimiento informativo y argumental notable. El narrador, al resaltar lo dicho por medio de su intervención directa, capta la atención del oyente sobre el enunciado mismo y el elemento comentado, haciendo aparecer su comentario como algo recordado en el momento, que, aunque se suma a lo anterior, parece más importante y se destaca en su presentación ${ }^{42}$.

\section{El método narrativo y la identidad de los personajes}

Zumstein ha expresado de forma clara la finalidad del método narrativo. Dicho fin consiste en reconstruir las operaciones por las cuales una obra se eleva sobre el fondo opaco del vivir para ser donada por un autor a un lector, que al recibirla es pro-vocado a cambiar su actuación. El texto se convierte en la mediación por la que el hombre, alejándose de sí mismo, se comprende a sí mismo. Gracias al texto, se accede a nuevas posibilidades de ser en el mundo. El lector, contrastado por el relato, es confrontado con una redescripción de la realidad llena de nuevas posibilidades y, así, el texto se convierte en una posibilidad de reconfigurar la comprensión del mundo y de la vida ${ }^{43}$.

A través de su punto de vista el narrador expresa su juicio sobre un personaje en función de su sistema de valores y de su concepción del mundo. De esta forma, configura la identidad narrativa del personaje; su carácter duradero, a lo largo del relato. La identidad narrativa de los personajes per-

\footnotetext{
42 Fuentes, "Parentéticos", 83.

43 ZuMSTEIN, Jean, "Narrativité et hermèneutique du Nouveau Testament. La naissance d'un nouveau paradigme", en Revue théologique de Lovain 40 (2009) 324-340, pp 327-335. En el ámbito de la literatura José Jiménez Lozano expresa el mismo fin para un relato: “... el hecho es que quien lee $\mathrm{u}$ oye la historia contada o la norma que se dicta, escruta esa escritura y cuenta luego algo a su respecto, con frecuencia una nueva historia sobre la historia leída, y como iluminación de la propia historia... Porque el contar una historia de una manera a la vez fiel pero distinta, y, desde la niñez, el leer una historia u oírla contar, tiene ya una doble vertiente: en primer lugar la necesidad dolorosa o placentera de revivir una historia de hombres, y luego como medio de conocimiento de lo real y del hombre en su dimensión existencial y no en su mera res extensa... El libro invade o desposa la vida del lector, y su destino. Es siempre susceptible de ser reinterpretado y, por tanto tronado contemporáneo, y el mismo libro rejuvenece al lector porque le dice siempre algo nuevo" (JIMÉNEZ
} 
mite al lector el acceso al mundo del relato, y a la vez le ofrece una forma de vida posible, una posibilidad de existencia concreta. Es el narrador quien guía al lector en esta elección o atracción hacia un personaje, mediante su punto de vista evaluativo y por un procedimiento de focalización. Este último, permite al narrador hacer partícipe al lector de su información sobre el personaje ${ }^{44}$. Es evidente que las notas del narrador, que por su enunciación están focalizadas, son un instrumento valioso para este procedimiento, especialmente en la focalización interna, que da acceso a la interioridad de los personajes (Jn 2,17.24; 4,44...); también en la focalización externa, que corresponde con lo que vería un observador (Jn 4,2; 5,9b...); y, de nuevo, especialmente en la focalización cero, que corresponde al plano que supera el marco temporal y espacial de la escena y dice más de lo que sabe ninguno de los personajes (Jn 2,21.22; 7,39 ... ${ }^{45}$. Así pues, es pertinente estudiar la caracterización de Jesús que aparece en estas notas ${ }^{46}$. Es la identidad narrativa la que permite al lector apropiarse de la identidad del personaje para interpretarse a sí mismo, porque la figuración de uno mismo a través de la mediación de otro puede ser un medio auténtico de descubrirse a sí mismo ${ }^{47}$.

Al final del evangelio, el propio narrador se dirige al lector informándole del objetivo perseguido por la obra, que es coherente con lo que ha expuesto Zumstein en su artículo “...éstas han sido escritas para que creáis que Jesús es el Cristo, el Hijo de Dios, y para que creyendo tengáis vida en su nombre" (Jn 20,31). En este versículo el narrador nos da tres informaciones importantes para comprender la naturaleza de su obra y su finalidad:

LozANo, José, La Biblia y el invento de narrar, 16-17 http://www.editorialconfluencias.com /wp-content/pdf-paginas/JIMENEZ-LOZANO-\%5B13-27\%5D.pdf) Y en otra parte: "El relato es la primera forma de conocimiento, pero es obvio que la existencialidad del hombre, su vivir, sólo a través del relato puede ser conocido" (ARBOnA, Guadalupe, Las llagas y los colores del mundo. Conversaciones literarias con José Jiménez Lozano, Encuentro, Madrid 2011, 112).

44 Marguerat, Daniel - Bourquin, Yves, Cómo leer los relatos bíblicos. Iniciación al análisis narrativo (=Presencia Teológica 106), Sal Terrae, Santander, 2000, 95-125.

45 Marguerat - Bourquin, Cómo leer, 118-121.

46 Para no alargar la extensión de este artículo y porque la metodología para caracterizar un personaje es más conocida no expondré aquí dicha metodología. Baste decir aquí que para descubrir la identidad de Jesús que el narrador quiere transmitir en sus notas debemos fijarnos en los rasgos del ser, de acción y de relación que aparecen en ellas. (Ver VALLES, José R., Teoría de la Narrativa: una perspectiva sistemática, Iberoamericana Editorial, Madrid 2008; Álamo, Francisco, "La caracterización del personaje novelesco: perspectivas narrativas", en Revista Signa 15 (2006) 189-213, 198-199; CAÑELLES, Isabel, La construcción del personaje literario. Un camino de ida y vuelta, Ediciones y Talleres de escritura creativa Fuentetaja, Madrid 1999).

47 Ricoeur, Paul, Historia y narratividad, Paidós, Barcelona 1999, 215-230. 
el evangelio es una narración, que quiere revelar la identidad de Jesús como el Cristo el Hijo de Dios, para crear una relación entre los lectores y Jesús: la fe.

\section{Las notas cristológicas del Prólogo de Juan (Jn 1,17-18)}

Las primeras notas cristológicas que encontramos en el relato joánico se encuentran al final del prólogo (vv. 17-18). Estas dos notas juegan un papel fundamental en la intratextualidad de todo el relato, ya que crean un puente entre el prólogo y la narración propiamente dicha ${ }^{48}$. Por su posición final comentan todo el prólogo, especialmente los versículos 14 y $16^{49}$.

\section{Jesús Mesías}

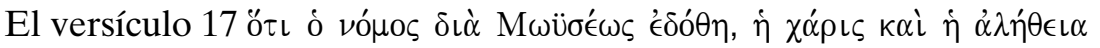

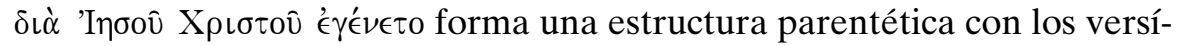
culos 14 y 16 que aparecen separados por la nota del versículo 15 referida a Juan Bautista. Los tres versículos aparecen relacionados por las expre-

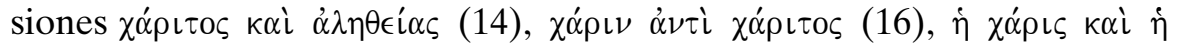
$\alpha \lambda \grave{\eta} \theta \in \iota \alpha$ (17). En el v14 se dice que el Logos encarnado ha recibido la plenitud de la gracia y la verdad; ahora, la nota permite al lector identificarlo con Jesús Mesías ${ }^{50}$ y a éste como la fuente de la gracia y la verdad que los miembros de la comunidad han recibido como gracia sobre gracia ${ }^{51}$. Este es el fin primordial y básico de esta nota, una información muy valiosa que recibe el lector para leer correctamente el resto de la historia y que los personajes no tienen.

Por medio de esta nota, el narrador caracteriza al personaje con un nombre propio y por medio de sus acciones, en contraste con otro personaje y sus acciones.

48 ZuMSTEIN, "Le prologue, seuil du quatrième èvangile", en Recherches de Sciencie Religieuse 83 (1995) 217-239, 228.

49 VIDAL, Los escritos, 384-391.

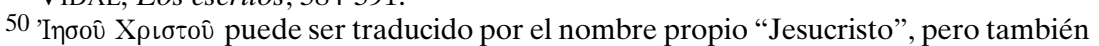
podemos traducir literalmente por "Jesús Mesías", como aposición, ya que el mismo narrador, más adelante, nos indicará que así lo debe entender el lector (Jn 1,41; 4,25).

51 MAC LEOD, David J., "The Benefits of the Incarnation of the Word: John 1:15-18", en Bibliotheca Sacra 161 (2004) 179-193, 183. 
El versículo 17 se hace eco de la escena de la entrega de la Ley a Moisés en el Sinaí. Moisés y la Ley son figuras claves en la tradición judía. El término Ley se puede extender a toda la Escritura, como hace el evangelio al referirse de esta manera al libro de los Salmos (Jn 10,34; 12,34;

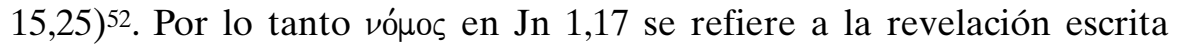
entregada a Moisés, como queda confirmado a continuación en 1,45 y más adelante en labios del propio Jesús en 5,46.

Así pues, en el evangelio de Juan, la Ley no tiene primariamente un carácter ético, sino que tiene más que ver con el concepto de Torah del judaísmo rabínico, que se refiere a la legislación basada en el Pentateuco $(1,45 ; 7,51 ; 8,31)$ o en toda la Escritura $(J n 7,19 ; 7,49 ; 12,34)^{53}$. Para Juan, la Ley es un don de Dios que fue dado a través de Moisés, pero el nuevo y último don ha llegado con Jesús. La Ley y el Logos no se identifican sino que son dones cualitativamente diferentes, donde el nuevo don reemplazará al anterior, como se desarrollará a lo largo de la narración ${ }^{54}$. Ciertamente, la Ley expresa la voluntad divina pero no alcanza el fin último de la revelación de Dios. Es ahora, en Jesús, cuando acontece la plenitud de gracia y verdad, manifestación definitiva y plena de Dios (vv.14.16) ${ }^{55}$.

Esta nota se convierte en una clave interpretativa de las acciones de Jesús para la lectura correcta de todo el evangelio. Jesús no es un cuerpo extraño en la gran tradición de la Escritura, sino su cumplimiento. La tradición joánica ha creado y recreado las palabras y hechos de Jesús y la Escritura para caracterizar a Jesús como la personificación de la Torah. Todo lo que en la tradición judía se atribuye a la Ley (vida, luz, agua, alimento), se atribuye ahora a Jesús sin que haya confusión entre los dos. De esta forma, la Ley, primer don de Dios, se convierte en testigo de Jesús ${ }^{56}$.

52 LOADER, Willian R. G., "Jesus and the Law" en VAN Belle, Gilbert - VAN DER Watt, Jan Gabriël -Maritz, P.J. (eds.), Theology and Christology in the Fourth Gospel (=Bibliotheca Ephemeridun Teheologicarum Lovaniensium 184), Leuven University Press, Leuven 2005, 136-137; KIM, Stephen. S., "The Literary and Theological Significance of the Johannine Prologue", en Biblotheca Sacra 166 (2009) 421-435, 426. El profesor Ska ante la relevancia que Moisés y la Ley han adquirido en el canon de la Escritura hebraica, que se manifiesta en la misma distribución de los escritos. Los profetas son considerados como la actualización de la Ley de Moisés y los libros sapienciales como una meditación de la misma (SKA, Jean Louis, Introducción a la lectura del Pentateuco. Claves para la interpretación de los cinco primeros libros de la Biblia (=Estudios Bíblicos 22), Verbo Divino, Estella 2001, 2331.

53 Maronde, Christopher Allan, "Moses in the Gospel of John", en Concordia Theological Quartely 77 (2013) 23-44, 27.

54 LOADER, “Jesus”, 139.

55 Zumstein, El evangelio según Juan 1-12 (=Biblioteca de Estudios Bíblicos 152), Sígueme, Salamanca 2016, 82.

56 LOADER, “Jesus", 149-150. 
Jesús es caracterizado como Mesías que hace presente y actualiza la gracia y la verdad, términos que se hacen eco de los capítulos 33-34 del Éxodo57. "Gracia" y "verdad" aparecen como sinónimos de los términos que definen el nombre de Yahvé en Ex 34,6, pues son las traducciones de hesed y amad. Hesed es la ternura o la misericordia de Dios al elegir a Israel y su expresión a lo largo de la Alianza. Amad es la fidelidad de Dios a esas promesas y a su elección ${ }^{58}$, ambas se realizan en Jesús como gracia y verdad.

El término gracia no vuelve a aparecer como tal en la narración; su significado y contenido se muestra en el cuerpo del relato en la vida y entrega de Jesús como amor de Dios que le impulsa $($ Jn 17,18), que se pide para sus discípulos (Jn 17,21.23) ${ }^{59}$ y sobre todo como el amor de Dios que aparece en la entrega de su Hijo por el mundo (Jn 3,16).

Al contrario de lo que ocurre con el término "gracia", "verdad" se convierte en un término clave en la trama del relato: manifiesta la fiabilidad y la firmeza del amor de Dios en lo que se refiere a su alianza, que se ha hecho acontecimiento en Jesús. Al mismo tiempo, en el evangelio de Juan, es también la realidad divina que posee el Logos encarnado (Jn 1,14); por lo cual Jesús, Logos encarnado, es la realización de esa realidad divina, es la autorevelación de la fidelidad de Dios que se hace presente y de hecho transmite la vida eterna (Jn 5,24-25) ${ }^{60}$.

Jesús no es un simple mediador sino la fuente de estos dones para los hombres, Moisés transmite lo que Dios le ha revelado de él, por el contrario, Jesús transmite los dones de Dios mismo ${ }^{61}$. ¿Por qué esa diferencia? Porque Jesús Mesías es el Logos encarnado anunciado en el versículo 14. Así, el narrador da al lector una clave interpretativa para el resto del relato. Jesús es presentado como el auténtico cumplimiento de las esperanzas de una redención escatológica. En él ocurre el verdadero y adecuado cumplimiento de las profecías y las esperanzas bíblicas, aquel en quien Israel debe-

57 Maronde, "Moses", 26.

58 Brown, Raymond, El evangelio según Juan, I Cristiandad, Madrid 1999, 208-209.

59 PAinter, John, "The Prologue as an Hermeneutical Key to Reading the Fourth Gospel”, en Verheyden, Jozet - Oyen, Geert van - Labahn, Michael - Bieringer, Reimund, Studies in the Gospel of John and its Christology. Festschrift Gilbert van Belle (=Bibliotheca Ephemeridum Theologicarum Lovaniensum 265), Peeters, Leuven 2014, 58.

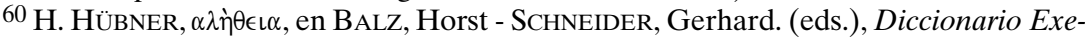
gético del Nuevo Testamento (=Biblioteca de Estudios Bíblicos 90), I, Sígueme, Salamanca 1996, 171-180. Sigue siendo una buena síntesis de este concepto en el evangelio de Juan el excursus de Schnackenburg en su comentario ya clásico (SCHNACKENBURG, Rudolf, El evangelio según Juan, II, Herder, Barcelona 1980, 264-280.)

61 MAC LeOD, "The Benefits", 186. 
ría hallar la expresión definitiva de la fidelidad y del designio redentor de Dios 62 .

La venida del Mesías es un acontecimiento esperado y conocido por todos los personajes del relato: los fariseos y las autoridades de Jerusalén (Jn 1,20.25), los discípulos de Jesús (Jn 1,41), la samaritana (Jn 4, 25.29) y la multitud (Jn 7). Pero en el relato se debate sobre su identidad: ¿quién es el Mesías?; y sobre su origen: ¿de dónde viene el Cristo? El lector asiste a esas disputas (Jn 7,25-31.40-44), conociendo ambas respuestas. El narrador también informa al lector de las consecuencias nefastas para sus seguidores de reconocer a Jesús tal identidad (Jn 9,22).

\section{Dios, Unigénito}

Pero aún el lector puede albergar una duda: ¿cómo es posible que Jesús realice la "gracia" y la "verdad"? Para resolver esta cuestión el narrador añade una digresión en el v.18, que sirve de fundamento al enunciado del versículo 17 y permite desvelar otro aspecto de la identidad de Jesús: su relación única con Dios y su divinidad, lo cual fundamenta la superioridad y singularidad de su revelación.

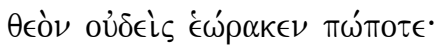

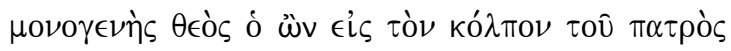

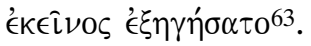

El versículo 18 se relaciona con la nota anterior por la evidente alusión

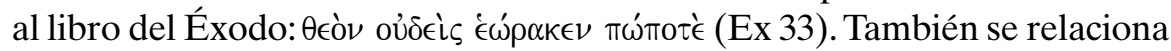
con el versículo 14, pues el Logos encarnado ha recibido la gloria de $\mu$ ovô $\gamma \in \nu 0 \hat{c}$. De esta forma, el lector puede concluir que Jesús Mesías es el Logos

\footnotetext{
62 Hurtado, Larry W., Señor Jesucristo. La devoción a Jesús en el cristianismo primitivo (=Biblioteca de Estudios Bíblicos 123), Sígueme, Salamanca 2008, 410.412.

63 En el versículo 18 aparece un problema textual significativo. Son posibles distintas

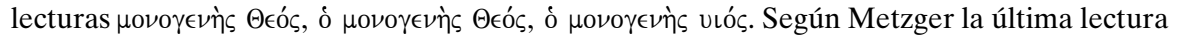
es el resultado de una asimilación de Jn 3,16.18 y 1Jn 4,9 (Metzger, Bruce M., A Textual Commentary on the Greek New Testament, Deutsche Bibelgesellschaft-United Bible Societies, Stuttgart-New York ${ }^{2}$ 1994, 169-170). Schnackenburg opina que cualquiera de las lecturas está en armonía con la imagen de Cristo que se irradia en el evangelio, por lo que adoptar una u otra no cambia nada sustancialmente (SCHNACKENBURG, Rudolf, El evangelio según San Juan, I, Herder, Barcelona 1980, 293-294). Atendiendo al peso de los testigos y la refe-

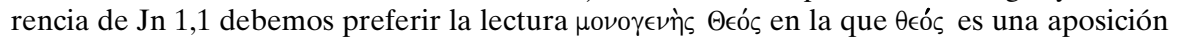

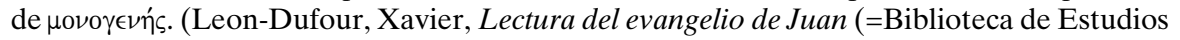
Bíblicos 68), I, Sígueme, Salamanca 1993, 105.).
} 
encarnado (v.17) y también el Unigénito. Los tres versículos hablan del mismo personaje. Pero la nota añade algo más: Jesús Mesías Unigénito es Dios, vinculando este versículo con el primero del Prólogo Ev áp $\chi \underline{n} \hat{\eta} \nu$ ó $\lambda$ ó 2.14.17-18 están relacionados entre sí y relacionan las figuras del Logos preexistente, el Logos encarnado y Jesús. Los versículos 1-2 hablan de la relación entre el Logos y Dios, que en el 14 aparece en términos de padre e hijo. En el 17 se identifica ese Logos encarnado con Jesús, que no ha perdido su condición divina y su relación con Dios, como indica la nota del versículo 18.

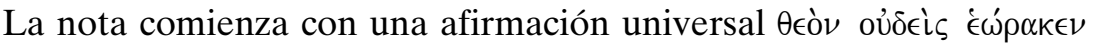
$\pi \omega \dot{\pi}$ otè. Es una afirmación sobre Dios mismo que está recogida en la escena del Éxodo en la que Dios se revela a Moisés (Ex 33,20-23). Ante la imposibilidad de ver a Dios, su conocimiento y su revelación sólo son posibles si él mismo toma la iniciativa y se da a conocer ${ }^{65}$. Ahora, un nuevo conoci-

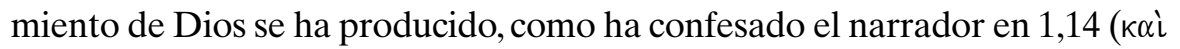

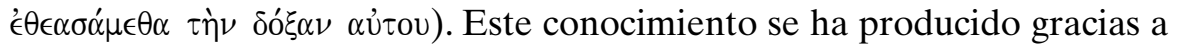

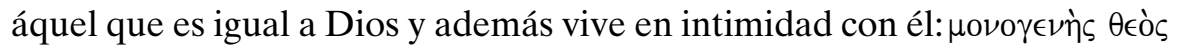

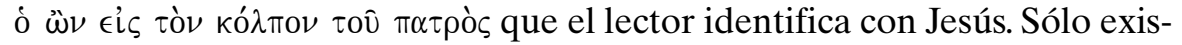
te este camino para conocer a Dios, como afirma el autor de la primera carta de Juan (1Jn 4,12).

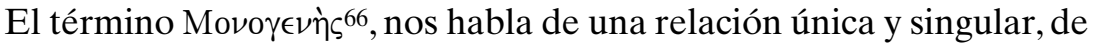
amor y comunión con un lenguaje muy próximo a las relaciones familiares. Jesús, al ocupar ese lugar en relación con el Padre, conoce sus secretos y comparte su misma naturaleza divina; al poseer esa intimidad está capacitado para darle a conocer ${ }^{67}$. Este término vuelve aparecer en el cuerpo del

${ }^{64}$ PainTer, "The Prologue”, 59. También J. Staley (Staley, Jeffrey Lloyd, "The Structure of John's Prologue: Its Implications for the Gospel's Narrative Structure”, en The Catholic Biblical Quarterly 48 (1986) 241-263) y Culpepeer (Culpepeer, R. Alan, "The Pivot of John's Prologue", en New Testament Studies 27 (1980-81) 1-31)

65 Zumstein, El evangelio, 83.

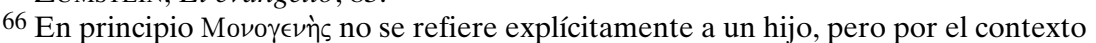
y el uso podemos entenderlo en el ámbito de las relaciones paterno-filiales, sobre todo en el versículo 18 en el que "Dios" y "Padre" aparecen identificados.

${ }^{67}$ MAC LEOD, "The Benefits" 191. Esta idea era familiar a los lectores del evangelio de Juan que conocen las relaciones entre el padre y el hijo dentro de las familias. El hijo debía ser como su padre, algo testimoniado también en la Escritura (Eclo 30,4; 44,10-11). La íntima unión entre el padre y el hijo es el fundamento de la estructura familiar de la antigüedad. De modo análogo la íntima unión entre Dios y Jesús asegura la revelación del relato (cf. GUIJARRO, SANTIAgo, Fidelidades en conflicto. La ruptura con la familia por causa del discipulado y de la misión en la tradición sinóptica (=Plenitudo Temporis 4), Publicaciones Universidad Pontificia Salamanca, Salamanca 1998, 139). 
relato en Jn 3,16, en Jn 3,18 y en la primera carta de Juan (1Jn 4,9). En los tres casos está acompañado del término viov̂ y no $\theta$ єós lo que permite considerar el término Hijo como sinónimo de divinidad en el cuerpo de la narración.

De esta forma, se realiza una importante conexión con el cuerpo del evangelio $(1,14.18 ; 2,16 ; 3,16.18 ; 3,35 ; 5,20)$ : en el Prólogo no aparece el término hijo referido a Jesús, pero sí la referencia al Padre en los versículos 14 y 18. En el cuerpo del relato, como hemos visto, aparece el término hijo unido al de Unigénito, referido a Dios y no a Padre. La elección del término Dios y no Padre en 3,16.18 puede deberse a que el interés del versículo se centra en la relación con el mundo y no con el Hijo. Un dato más nos hace pensar en lo adecuado de nuestra conclusión: mientras que la relación Dios mundo se expresa en aoristo (Jn 3,16.18) la relación Padre- Hijo se expresa en presente $(\mathrm{Jn} 3,35 ; 5,20)$, algo que aparece ya en nuestra nota que presenta a Jesús en el seno del Padre 68 . Hay que entender por tanto que Dios Unigénito en el prólogo es sinónimo de Hijo Unigénito en el cuerpo del relato. En esto reside la superioridad y la realidad misma de una revelación nueva y mayor que la de Moisés: Jesús, Mesías, Unigénito es el Hijo de Dios, Dios mismo, que da a conocer al Padre a los hombres y realiza su gracia y verdad ${ }^{69}$. En Juan, la condición divina y trascendente del título Hijo está enfatizada y aparece como en este caso de forma explícita: Jesús, al ser el Logos encarnado, posee un origen celestial y es divino. Será esta categoría la que Jesús utilice en sus palabras para definirse a sí mismo (Jn 3,16-17.3536; Jn 5,19.20.30) y aparecerá de forma implícita al referirse a Dios como a su Padre (Jn 14, 2.10-11.28-31) ${ }^{70}$.

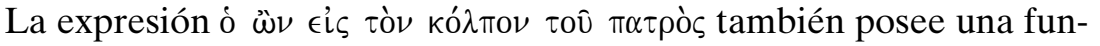
ción informativa significativa para lo que continúa: Jesús Mesías, Dios Unigénito, no ha perdido su unión con Dios Padre en su encarnación; en su ministerio terreno continúa unido a Dios, lo cual se manifiesta a lo largo de la narración (Jn 12,45;14,7-11). El que habla y actúa en la tierra es el Logos que se revela en el Prólogo, tanto encarnado como eterno, de modo que las afirmaciones sobre la preexistencia, la proximidad con Dios y la divinidad del Logos aparecen en el testimonio de Jesús sobre sí mismo ${ }^{71}$. Al final del prólogo, el lector comprende que el misterio de Dios se ha hecho presen-

68 PAINTER, John, “Identity in the Fourth Gospel”, en The Covenant Quarterly 72 (2014) 247-260, 253.

69 Maronde, "Moses", 26.

70 Hurtado, Señor Jesucristo, 413-415.

71 SCHNACKENBURG, El evangelio, I, 294. 
te en el enigma del mundo y de la historia, por medio del Logos encarnado, perfectamente identificado con Jesús ${ }^{72}$.

La nota concluye exponiendo la misión del Unigénito en el mundo:

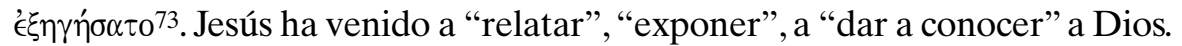
Con sus palabras Jesús se convierte en la interpretación de Dios en el mundo, su testigo (Jn 3,11.32; 5,37; 8,38). El uso de este verbo hará caer en la cuenta, aún más, al lector de la relevancia de las palabras de Jesús en la narración y entender las afirmaciones tan radicales sobre su propia palabra (Jn 5,24; 6,63). Esta última nota del narrador revela también la plena dignidad divina y la plena capacidad de revelación de Jesús.

La nota concede un rango especial al relato que a continuación se va a desarrollar. No le pasará desapercibido al lector, que el Discípulo Amado, garante del relato (Jn 19,35), ocupa la misma posición respecto de Jesús, que Jesús respecto del Padre. Del mismo modo que Jesús es el único que ha visto a Dios porque está en el seno del Padre, y sus palabras constituyen un testimonio del Padre (Jn 3,11), el Discípulo Amado ha visto a Jesús en el momento más crítico de su vida $($ Jn 19,35$)$ y da testimonio de él y su testimonio, el relato, es verdadero (Jn 21,24) porque estaba en el seno de Jesús $(\text { Jn } 13,23)^{74}$.

El "haber visto" jugará un papel importante como hilo narrativo en el evangelio de Juan. Desde este punto de vista el narrador, al presentar a Jesús como el testigo de Dios, hace que su testimonio genere un relato "de Jesús sobre Dios" que permite a los que han visto a Jesús ver a Dios; cuando Jesús no está y no es accesible por la mirada, el testimonio del Discípulo Amado, genera un relato "de Jesús sobre Jesús" que ocupa el lugar del propio Jesús y que por la fe otorga los mismos beneficios que su presencia (Jn 2,11; Jn 20,30-31). Por eso, esta nota es relevante también para considerar la naturaleza del relato como Escritura ${ }^{75}$. Jn 20,30 da testimonio del nacimiento de

\footnotetext{
72 PAINTER, "The Prologue", 38-39.

73 X. Leon-Dufour traduce $\epsilon^{\xi} \xi \eta \eta \dot{\sigma} \sigma \alpha \tau o$ del versículo 18 como "ha contado", una traducción más literal que la de "revelar" en el sentido técnico de revelar misterios divinos. SCH-

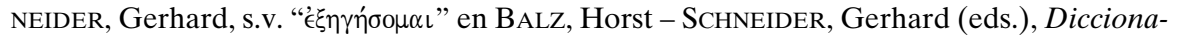
rio, I, 1436-1437), pero que sí coincide con la finalidad señalada para este versículo por el narrador, porque lo que viene a continuación es la puesta por escrito de lo que Jesús "ha contado", es decir, un relato (LEON-Dufour, Lectura, I, 110-111.).

${ }^{74}$ Zumstein, Jean, "La naisance de la notion d'Écriture dans la litterature Johannique", en Auwers Jean Marie - De Jonge, H.J. (eds.), The Biblical Canons (=Bibliotheca Ephemeridum Theologicarum Lovaniensium 163), Leuven University Press, Leuven 2003, 375.

75 Mirguet, Francoise, "Voir la mort de Jésus quand le "voir" se fait récit", en VAN Belle, Gilbert, (ed.), The Death of Jesus in the Fourth Gospel (=Bibliotheca Ephemeridum Theologicarum Lovaniensium 200), Leuven University Press, Leuven 2007, 469-479.
} 
una nueva Escritura destinada a convertirse en el libro de la fe de los lectores junto con las antiguas Escrituras judías ${ }^{76}$.

Esto permite leer la nota de Jn 1,18 como el título de la historia de Jesús Mesías, interpretación lograda de Dios ${ }^{77}$, que se va a desarrollar a continuación. En ella Dios se revela de forma última y plena en la historia del hombre Jesús. Se produce una cristologización radical de la cuestión de Dios: Jesús es singular por su relación única con Dios e, inversamente, Dios no tiene otra manifestación para los hombres que no sea Jesús ${ }^{78}$. No se puede encontrar a Dios sino en Jesús y Jesús no puede ser encontrado sino en el evangelio en tanto que Palabra de Dios.

\section{Conclusión}

Son estas dos notas las que permiten al lector pasar del mito a la historia; del tiempo primordial de los orígenes al tiempo histórico; de la realidad divina inaccesible a la realidad del mundo donde se revela. Gracias a estas notas, la Palabra trascendente se convierte en un rostro que puede ser contemplado, el Preexistente es un hombre concreto que puede ser comprendido ${ }^{79}$.

Por medio de estas dos notas el narrador une la afirmación mesiánica y la de la filiación divina antes de comenzar el relato. Esta asociación está enraizada en la tradición bíblica: el rey davídico es el Hijo de Dios (Sal 2; 110). Estas tradiciones reales se recuerdan y se asimilan para aplicarlas a Jesús en el evangelio de Juan. Pero el énfasis de Juan en la divinidad de Jesús no es tolerable para los judíos. Los judíos, en el contexto del discurso del buen Pastor, le preguntan a Jesús si verdaderamente es el Mesías (Jn 10,24); Jesús lo admite abiertamente y pone como testigo a las obras que hace en nombre de su Padre (Jn 10,25) apelando a la unidad con él de una forma singular y única reivindicando su filiación y divinidad (Jn 10,30) lo cual, para los oídos de los judíos es una blasfemia (Jn 10,33), algo que el lec-

76 ZuMSTEIn, Jean, El evangelio según Juan (13-21), Sígueme, Salamanca 2016, 377. La misma opinión recoge MolONEY, Francis J., "The Gospel of John as Scripture", en Catholic Biblical Quartely 67 (2005) 454-468.

77 ZuMstein, El evangelio, 83. El título es ya una clave interpretativa del texto. Sus funciones son las de identificar la obra, designar su contenido y atraer al público (Alvarado, Maite, Paratexto (=Enciclopedia Semiológica), Eudeba, Buenos Aires 2006, 47-50). Hay que tener en cuenta que no es un título, estrictamente hablando, pero cumple estas tres funciones sobre todo las dos últimas.

78 ZuMSTEIN, El evangelio, 83.

${ }^{79}$ ZuMSTEIN, "Le prologue", 238. 
tor ya conoce gracias a las notas del capítulo 5 -aunque allí no está explícitamente unida a la categoría de Mesías-. El lector conoce desde el principio esta relación que define la verdadera identidad del Mesías, es realmente el Logos encarnado, Jesús, que viene verdaderamente de Dios y está en Dios (Jn 8,12-20.25) ${ }^{80}$. De esta forma, se posee una clave hermenéutica esencial para comprender las acciones y las palabras de Jesús que se recogerán en el relato y que le permitirán alcanzar el objetivo último del mismo: creer que Jesús es el Mesías y el Hijo de Dios, como anota el narrador al final de la obra (Cf. Jn 20,31).

En resumen, con estas dos notas el protagonista del relato queda caracterizado de forma completa por medio de los nombres que le son atribuidos, por sus relaciones y por sus acciones. El personaje es nominado por un nombre propio, Jesús, al que se le añaden tres nombres comunes que lo determinan: Mesías, Unigénito y Dios. Jesús aparece relacionado con Dios, está en su seno y le da conocer, es el testigo del Padre en la tierra. Por su relación con Dios aparece en una relación de superioridad respecto a Moisés y a su revelación, que quedan constituidos como testigos de Jesús ante los judíos. En lo que respecta a los hombres, Jesús es aquel que otorga la gracia y la verdad que la Ley no puede dar. Esto lo realiza Jesús a través de sus acciones y sus palabras. Las acciones revelan su gloria y las palabras dan a conocer al Dios que nadie ha visto jamás.

\section{PAPel de estas notas en el Relato del eVAngelio}

Estas notas juegan un papel imprescindible para comprender adecuadamente la naturaleza y el contenido del relato sobre Jesús que se presenta a continuación y son la base de algunas otras notas cristológicas del narrador.

\section{El Prólogo a la luz de estas notas cristológicas}

Las dos notas nos permiten entender el prólogo como un movimiento que hace perceptible el plus de sentido sobre la persona de Jesús que en el relato evangélico es cuestionado y puesto en tela de juicio. Él es el Logos encarnado, igual a Dios, que va a ser rechazado y crucificado; la luz y la vida de los hombres que va a ser ignorada.

\footnotetext{
${ }^{80}$ Hurtado, Señor Jesucristo, 409.
} 
De esta forma, las notas colocadas al final del prólogo permiten redefinir la función del mismo. No se trata de un mero resumen del evangelio, sino del marco y la clave hermenéutica con los que el relato debe ser leído. De este modo se le protege al lector frente a los malos entendidos que van aparecer en el relato, y se le ofrecen diferentes estrategias para comprenderlo. Para realizar esta función, las notas juegan un papel crucial al revelar, de forma más profunda, la identidad del protagonista principal del drama que se va a desarrollar ${ }^{81}$. Son las dos notas finales las que incrementan la importancia teológica y literaria de todo el prólogo ${ }^{82}$. No es extraño que algunos autores se refieran a estos versículos como la cumbre del prólogo, donde se condensa la teología de Juan y a la vez se indica el tema del cuarto evangelio 83 .

Las notas de Juan 1,17-18 tienen también su importancia literaria, porque ambos versículos otorgan al narrador el fundamento para elegir su estrategia a la hora de presentar su relato. En estos versículos se relacionan las acciones de Jesús (v.17) y sus palabras (v.18), por lo que no es extraño encontrar en el relato las acciones de Jesús comentadas, explicadas o clarificadas por medio de sus palabras o sus diálogos con los judíos, sobre todo hasta su pasión y muerte ${ }^{84}$; lo que constituye una de las características principales del cuarto evangelio.

De la misma manera juegan un papel en la estructura general de la obra. Las notas de Jn 1,17-18 coinciden en la forma de caracterizar a Jesús, que encontramos en la nota final del narrador (Jn 20,30-31) ${ }^{85}$. En ella, el lector vuelve a encontrar la caracterización inicial de Jesús como Mesías y como Hijo de Dios, por lo que el lector entiende perfectamente que la narración ha llegado a su fin y que comenzó con la presentación de este personaje en el final del prólogo y no antes. El relato ha cumplido su finalidad y ahora el lector es invitado a reconfigurar su propia identidad a la luz de la identidad de Jesús, Mesías Hijo de Dios, convirtiéndose en creyente.

81Zumstein, "Le prologue", 239; PAinter, "The Prologue", 39; Matera, Frank, J., New Testament Christology, Westminster John Knox Press, Louisville 1999, 217.

82 KIM, "The Literary", 435.

83 Schnackenburg, El evangelio, I, 296; Zumstein, El evangelio, 83.

84 GuiJarro, Los cuatro, 456.

85 La mayoría de estudiosos coinciden en que el capítulo 21 es un epílogo de la narración que por sus características paratextuales nos permiten hablar de Jn 20,30-31como conclusión, propiamente dicha, del relato. Alvarado, Paratexto, 55; ZuMSTEIN, "Le processus", 169. 


\section{Jn 1,17-18 y el género literario del evangelio}

$\mathrm{Al}$ considerar Jn 1,18 como el título del relato que sigue, descubrimos una cierta semejanza con el comienzo del evangelio de Marcos (Mc 1.1), en el que el protagonista es caracterizado de una forma muy similar, por no decir idéntica, y que se va confirmando a lo largo del relato (Mc 8,29;15,39). J. Painter relaciona el comienzo del evangelio de Juan con el comienzo del evangelio de Marcos, pero lo reduce sólo al papel asignado a Juan Bautista en el prólogo juánico. Creemos que también en la nota del narrador se puede encontrar esa relación ${ }^{86}$. Consideramos que el evangelio de Juan es una interpretación creativa de la tradición sobre Jesús, de la que buena parte es compartida con los sinópticos. La originalidad de Juan reside en la búsqueda del sentido profundo de las acciones y enseñanzas de Jesús desde la convicción de que es el Logos encarnado. Las relaciones del cuarto evangelio con los sinópticos es compleja; adoptamos aquí la posición más ponderada expresada por el profesor Guijarro: el autor del evangelio de Juan conoció los sinópticos, pero no los utiliza como referencia fundamental, pudiendo así componer un evangelio que integrase tradiciones distintas sobre Jesús ${ }^{87}$. Esto no excluye que Juan utilizase el mismo esquema literario que adoptaron los sinópticos: el de las vidas helenísticas ${ }^{88}$. El prólogo cumple con las tres funciones que Malbon atribuye a los comienzos de los evangelios: conectar al lector con el texto, relacionar el texto con otros textos y crear el mundo del relato ${ }^{89}$. Estas mismas funciones -interacción con el lector, relación de intertextualidad e intratextualidad- descubre Zumstein en el prólogo, lo que confirma su papel como inicio de la bios de Jesús ${ }^{90}$. Estas tres funciones las realiza el prólogo joánico por lo que creo que adquiere la misma función que los otros comienzos de los evangelios. Las tres funciones se concentran en las notas de 1,17-18: identifica al protagonista del texto para el lector, se relaciona a Jesús con la revelación de Moisés recogida en la Ley (Escritura) y define, para el lector, el relato como el testimonio de Jesús sobre Dios. Podemos inducir que al igual que el autor del relato de Marcos quiso escribir un relato con los mismos fines que perseguían las vidas antiguas y adoptó su esquema literario, así también nues-

86 PAINTER, "The Prologue", $43-44$.

87 GuiJarro, Los cuatro, 99.527.

88 GuiJarRo, Los cuatro, 57-60.

${ }^{89}$ Malbon, Elizabeth Struthers, "Ending at the Beginning: A Response”, en Semeia 52 (1990) 175-184.

90 ZuMSTEIn, "Le prologue", 228. 
tro relato responde a ese esquema literario y al mismo fin de los relatos de vidas antiguas como el resto de los evangelios sinópticos.

Esta opinión se ratifica gracias a la contribución de A.D. Myers ${ }^{91}$, que muestra cómo en el prólogo juánico aparecen los tópicos de los comienzos de las "vidas antiguas": orígenes, educación, hechos y comparaciones con otros personajes. Entre estos, el tópico más importante es el de los orígenes que muestra la naturaleza única de Jesús: es la perfecta imagen de su Padre, como Unigénito posee la intimidad con su Padre y esto le otorga la superioridad sobre todos los demás $(\mathrm{Jn} 1,18)$. Por otra parte, el prólogo excluye cualquier tipo de educación formal, algo que será criticado en el relato (Jn 7,14-15), ya que muestra que Jesús tiene acceso al Padre y recibe las distintas instrucciones de Él (Jn 5,19-30; 6,37-38; 7,16-17; 8,28; 10,37$38 ; 12,49.50)$, por lo que no requiere una especial educación humana, y así, el tópico de la educación es sustituido por la referencia al lugar que ocupa al lado del Padre (Jn 1,18). También aparecen los hechos de Jesús, el Logos encarnado, que aparece como el mediador y protector de la vida, legitimado para ofrecer la vida eterna del Unigénito de Dios (Jn 1,12-13) como quedará explicitado en Jn 5,26. De la misma manera, aparece el tópico de la comparación con otros personajes, que refuerza la autoridad y la superioridad de Jesús tanto respecto a Juan Bautista como a Moisés (Jn 1,17-18).

El esquema de las vidas Antiguas se divide en tres partes: orígenes del personaje, actuación y enseñanza pública, muerte del personaje y acontecimientos que la rodean ${ }^{92}$. El evangelio de Juan responde a este mismo esquema. Y el papel de las notas del narrador para fijarlo es relevante ya que encontramos notas cristológicas en lugares claves que delimitan las partes principales del evangelio: al final del prólogo (Jn 1,18), al final de la vida pública de Jesús y antes de su pasión (Jn 12,41 (38-41)) y en la primera conclusión del relato evangélico (Jn 20,30-31). Las tres notas están centradas en el protagonista Jesús, lo que nos dice que su identidad es el interés principal de la obra. La nota de Jn 20,30-31, que cierra el fin del evangelio, coincide con el fin de las vidas antiguas que quieren convencer y persuadir a sus lectores u oyentes que esta versión es la verdadera, entre otras opciones y versiones de la información sobre el personaje, y que el relato tiene una función didáctica para que su audiencia imite al héroe del relato

${ }^{91}$ Myers, Alicia D, Characterizing Jesus. A Rhetorical Analysis on the Fourth Gospel's Use of Scriptures in its Presentation of Jesus (=Library of New Testament studies 458), T\&T Clark, London- New York 2012, 61-69.

92 GuiJARro, Los cuatro, 465-466; MYERs, Characterizing, 37-38. 
Son las notas finales del prólogo las que juegan un papel crucial en la determinación de este género literario y las que permiten leer el evangelio como una vida antigua: al comienzo de su relato el autor ha introducido datos sobre el verdadero origen del protagonista, mostrando su carácter extraordinario y su honor, algo que no sería posible sin la identificación de Jesús con el Logos encarnado.

\section{Jesús y Moisés en el relato evangélico}

La nota del versículo 17 relaciona a Moisés con Jesús. Esta relación no es negativa ni polémica, sino de continuidad y superación. No existe para Juan un contraste absoluto entre Moisés que dio la Ley, por encargo de Dios, y Jesucristo que hace presente la gracia y la verdad divinas ${ }^{93}$. El narrador también relaciona el don de Moisés con el don de Jesús, lo cual permite leer el versículo 17 como una explicación al anterior (v.16), de forma que la ley de Moisés también se puede considerar como un acto de amor ${ }^{94}$. La ley es un don divino dado por Moisés, que sólo se puede cumplir creyendo en la revelación que trae Jesucristo (Jn 5,45-46). Moisés es un inter-

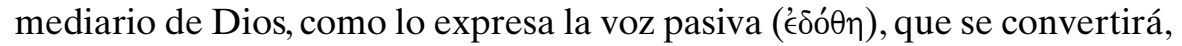
a lo largo del evangelio ${ }^{95}$, en testigo de Jesús, que es fuente de vida eterna y no un intermediario más de la salvación.

Tomando como base las dos notas finales, el narrador inicia su relato prestando testimonios sobre Jesús (Jn 1,19-34) que usan como garante a Moisés (Jn 1,35-51, sobre todo 1,45-51). De esta forma comienza a desarrollarse narrativamente la idea implícita en el versículo 17: Moisés y la Escritura dan testimonio de Jesús. Pero esto es insuficiente: Jesús revelará cosas mayores (Jn 1,51).En este punto el lector puede intuir en qué consisten esas cosas mayores: el don de la gracia y la verdad, algo que será confirmado en una nueva nota del narrador tras el primer signo de Jesús (Jn 2,11).

A lo largo del relato aparecerá que la única forma de creer en Moisés es creer en Jesús (Jn 5,46-47). Jesús y Moisés sólo aparecen enfrentados en boca de los judíos que malinterpretan la Ley, por lo que Jesús se referirá a ella en términos de "vuestra ley"96. El relato planteará la oposición entre

\footnotetext{
93 SCHNACKenburg, El evangelio, I, 291.

94 Brown, El evangelio, I, 210.

95 MARonde, "Moses", 23-26.

96 MARonde, "Moses", 23.
} 
Jesús y los judíos, utilizando como defensor y testigo de Jesús a Moisés (5,3940;9,13-34). El lector asiste a estos conflictos pertrechado con la importante clave de comprensión que le ha otorgado el narrador ${ }^{97}$.

Jesús continúa y plenifica la revelación de Dios que transmitió y enseñó Moisés, y ahora es rechazada por los judíos. El término que se utiliza para referirse a la actividad de enseñanza de Jesús $(\delta\llcorner\delta \alpha ́ \sigma \kappa \omega \nu)$ solo aparece en la voz del narrador y siempre señala el lugar donde se realiza $(6,59 ; 7,28 ; 8,20)$. Jesús enseña en el ámbito religioso judío donde se proclama la ley y se celebra la alianza, la sinagoga y el Templo (Jn 6,59;8,20). En estos lugares se produce el rechazo a Jesús, por lo cual estos ámbitos y lo que se conmemora en ellos aparecen superados y sustituidos por la persona de Jesús ${ }^{98}$, verdadero Templo de Dios (Jn 2,21). El contenido de su enseñanza se refiere a su propia identidad y su significado salvífico para los hombres, superando y transcendiendo el don dado por Moisés (Jn 6,48-51). Su enseñanza es una reinterpretación cristológica de la fe tradicional ${ }^{99}$, lo cual está en plena consonancia con la idea de Jn 1,17-18.

\section{Las palabras de Jesús y las Escrituras}

El narrador presenta a Jesús en las notas finales del prólogo como el que cumple las esperanzas escatológicas de Israel y como el que está en el seno de Dios y nos lo revela. De esta forma a lo largo del relato aparecerá como aquel en quien se cumplen las Escrituras y aquel cuyas palabras se convertirán también en dignas de fe como aquellas ${ }^{100}$.

Esto le permite al narrador insertar en el relato citas de la Escritura que evidencian su cumplimiento en Jesús, sobre todo en los lugares en los que su pretensión mesiánica y su condición de Hijo de Dios aparece contestada por la realidad (Jn 12,38-40), y más radicalmente en el momento de su muerte en Jn 19,24 y Jn 19,36. En el mismo contexto, la muerte de Jesús, el narrador hace notar que las palabras de Jesús que han aparecido anteriormente en el relato (Jn 3,14; 6,39; 10,28; 17,12) también se cumplen (Jn 18,9.32). La unión entre las palabras de Jesús y las Escrituras aparece por primera vez de forma explícita en la nota de Jn 2,22 que comenta toda la

\footnotetext{
97 PAinter, "The Prologue", 58. 51-69.

98 LIEU, Judith, "Temple and Synagogue in John”, en New Testament Studies 45 (1999)

99 ZuMSTEIN, El evangelio, 306.

100 SCHNACKENBURG, El evangelio II, 247.
} 
escena de la expulsión de los vendedores del Templo, ya que se refiere tanto a las palabras de Jesús (v.16.19) como a las Escrituras (v.17).

Gracias a Jn 1,18 el lector entiende las afirmaciones de Jesús sobre sus propias palabras a lo largo del evangelio (Jn 6.63; 8,28.31.38.51), y las que hacen de ellas otros personajes (Juan Bautista en 3,34; Pedro en 6,68). Esta Palabra muestra su poder y los efectos que produce en la curación del hijo del funcionario real (Jn 4,46-53). Un episodio que el narrador comenta con una nueva nota (Jn 4,54). Es la fe en la palabra de Jesús lo que ha convertido el milagro en un verdadero signo que les permite reconocer a Jesús como aquel que por su palabra es capaz de dar la vida. El funcionario real ha creído sin ver (Jn 20,29), ha creído en la palabra de Jesús antes de la resurrección, convirtiéndose en un creyente ideal antes de la Pascua, un verdadero modelo presentado al lector, que es invitado a pasar de una fe elemental a una fe plena sin el beneficio de un prodigio observable ${ }^{101}$.

Sus palabras aparecen como una de las causas por la que va a ser rechazado y acusado. La nota de Jn 8,20 se diferencia de otras intervenciones por la introducción del drástico incremento de violencia que aparece al final de la escena, cuando sus propios discípulos intenten apedrearlo $(\mathrm{Jn} 8,59)$ a causa de su predicación en el Templo. El contenido de la enseñanza a la que se refiere Jn 8,20 se relaciona también con las notas finales del prólogo. Jesús proclama su identidad como luz, en consonancia con la simbología de la fiesta de las Tiendas en la que está situada la escena (Zac 14,7), lo que le lleva a explicar su unión con el Padre (Jn 8,16). La nota contiene una diferencia con otra anterior $(\mathrm{Jn} 6,59)$, ya que hace referencia explícitamente a sus pala-

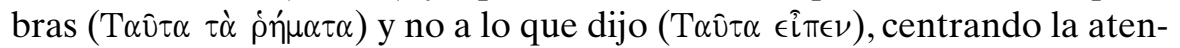
ción del lector en las palabras de Jesús que ya han sido caracterizadas como palabra de Dios, espíritu y vida y que tienen la capacidad de dar vida eterna (Jn 3,$34 ; 6,63.68)$ y se presentarán como palabra capaz de juzgar y como don del Padre y del Hijo que permanece en los discípulos (Jn 12,48; 15,7). Jesús no es un maestro cualquiera sino aquel que aporta la revelación directa de Dios, mostrando lo que se anotó en Jn 1,17-18.

\section{El verdadero origen de Jesús}

Partiendo de las notas finales del prólogo, el lector conoce el verdadero origen de Jesús, lo cual le da una posición privilegiada a la hora de adentrarse en el relato. Esta información es crucial, ya que la pregunta sobre su

101 ZuMSTEIn, El evangelio, 222. 
origen aparecerá en diversos momentos y será una cuestión muy debatida. Las noticias que conocen los personajes del relato sobre el origen de Jesús no son muy honorables (Jn 1,46, Jn 6,42, Jn 7,27.41-42.52, Jn 8,48). A todas estas discusiones el lector asiste desde una posición privilegiada y todas las noticias que recibe en su lectura quedan o relativizadas o superadas por el conocimiento de su verdadero origen: Dios ${ }^{102}$. Jesús responde a estas preguntas y acusaciones declarando explícitamente lo que el lector ya conoce acerca de su origen, gracias a lo cual el lector se ve confirmado en su lectura (Jn 3,12-13; 5,33-38; 7,28-29; 8,29.42.54-55) ${ }^{103}$.

Esta información permite al narrador incorporar tradiciones históricas que se refieren a Jesús, y que crean problemas de interpretación, pero que el lector está capacitado para entender. Un claro ejemplo es la nota de Jn 4,44. Tras la estancia en Samaría, el narrador retoma el itinerario (Jn 4,4445) que había comenzado en Jn 4,1-6. En el versículo 44 aparece una nota del narrador referida a Cristo que se ha convertido en un grave problema

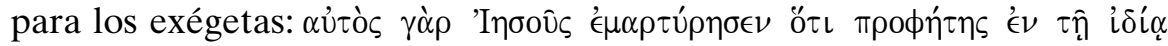

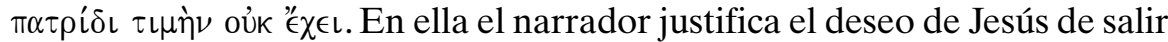
de Judea y trasladarse a Galilea. Este versículo va en contra de la noticia tradicional de que la patria de Jesús es Galilea (Mc 6,4; Mt 13,57; Lc 4,24) y de las noticias que el evangelio de Juan aporta sobre la patria de Jesús (Jn $1,45 \mathrm{~s} ; 6,42 ; 7,3.41 .52 ; 18,5.7 ; 19,19)$ identificada con Nazaret. Siguiendo el hilo de la narración y más allá del dato histórico o tradicional, la nota encaja perfectamente en la trama del relato. Jesús hasta ahora se ha manifestado públicamente en Jerusalén (Judea) y es el único lugar donde ha sido rechazado o al menos puesto en cuestión (Jn 2,19-20) ${ }^{104}$. El lector conoce que el verdadero origen de Jesús está con el Padre, en su seno (Jn 1,1.18) y que ha venido a los suyos y los suyos no lo recibieron (cf. Jn 1,11). Gracias al Prólogo el lector sabe cuál es la verdadera patria de Jesús y cómo el Logos encarnado ha sido rechazado por los suyos, por lo que la noticia en la dinámica del relato no causa problema alguno ${ }^{105}$.

102 De esta forma el lector entiende perfectamente los malentendidos que se dan en el evangelio y se crea la ironía característica del mismo, ya que basándose en la Escrituras los judíos rechazan a aquel que trae la verdadera y última revelación de Dios. Las notas refuerzan estos procedimientos característicos del evangelio (GUIJARRO, Los cuatro, 464; CulPePeER, Anatomy, 149-199).

103 Es necesario señalar que las discusiones del capítulo 7 toman como base la curación del paralítico del capítulo 5 , en el que el narrador ha anotado al lector que los judíos han "descubierto" la verdadera identidad de Jesús como Hijo de Dios y han decidido matarle (Jn 5,18).

104 Moloney, El evangelio, 172.

105 Moloney, El evangelio, 172. Como en otras notas, en esta también se puede traslucir la historia de la comunidad joánica que tuvo su origen en Judea y en un momento dado 


\section{La condición humana y divina de Jesús}

Las dos notas finales del prólogo hacen posible que a lo largo del evangelio Jesús aparezca con sentimientos humanos y a la vez con atributos divinos. Al mismo tiempo que muestra sentimientos humanos de amistad con la familia de Betania y llora la pérdida de Lázaro, también aparece su conocimiento extraordinario o sobrenatural de lo que ocurre o va a ocurrir (Jn 11,5.13.35).

La unión de las características humanas y divinas aparecen en una nota del narrador al final del segundo capítulo (Jn 2,24-25). Éste se concluye con una transición (Jn 2,23-25) en la que el narrador hace un balance de la actividad de Jesús en Jerusalén (v.23) que él mismo comenta por medio de dos notas en los versículos 24 y 25 . En el versículo 23 el narrador informa que muchos en Jerusalén creyeron en él porque habían visto sus signos. Esta noticia es objeto de un comentario por parte del narrador en el que se nos informa de que Jesús, por el contrario, no creía en ellos (es el mismo verbo utilizado para expresar la fe de los jerosolimitanos), ya que Jesús les conocía a todos (Jn 2,24). El v.25 explica la causa de ese conocimiento profundo de Jesús: conoce el interior del hombre y no necesita ningún testimonio.

El v.24 es la primera nota que informa al lector sobre un sentimiento

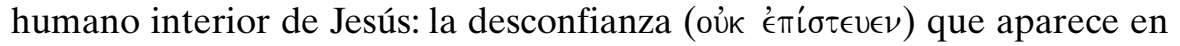
contraste con el sentimiento de los habitantes de Jerusalén, lo que indica que su fe es deficitaria, ya que entre los creyentes y Jesús existe siempre reciprocidad en su relaciones (Jn 1,12-13;3,16;11,26) ${ }^{106}$. Más adelante el narrador y el mismo Jesús informan al lector de otros sentimientos humanos (Jn 11,5.35-36; Jn 12,27). Por medio de estas notas el narrador acentúa la verdadera humanidad de Jesús, la realidad de su encarnación, que es compatible con el conocimiento sobrenatural que se explicará en la siguiente nota.

El v.25 explica la causa de ese conocimiento sobrenatural: es un atributo del Dios de las Escrituras (1Sm 16,7; Sal 7,10; 38,10; 44,22; 94,11; 139,1-4, Jer 11,20;17,10), lo que está en consonancia con lo dicho de Jesús en la nota de 1,18. Este conocimiento será puesto en evidencia por el narrador en nuevas notas a lo largo del evangelio sobre todo en el conocimiento de Jesús sobre aquel que le va a entregar (Jn 6,64.71). De esta forma

tuvo que salir de allí (BERnABÉ, Carmen, "Las comunidades joánicas: un largo recorrido en dos generaciones", en Aguirre, Rafael (ed.), Así empezó el cristianismo (= $\alpha \gamma o \rho \alpha 28)$, Verbo Divino, Estella 2010, 308-316). No debemos olvidar que el relato también recoge la historia de la propia comunidad (ZuMSTEIN, El evangelio, 27).

106 FARELLY, Nicolas, "John 2,23-25 What Kind of Faith is This", en Presbyterion 30 (2004) 37-45, 44. 
Jesús, a lo largo de todo el evangelio, es consciente de su suerte y de su destino (Jn 13,1).

Esta última nota caracteriza a Jesús como verdadero hombre en sus sentimientos y a la vez verdadero Dios por su conocimiento sobrenatural.

\section{Conclusión}

Las notas de 1,17-18 son claves para la lectura de todo el evangelio y la comprensión correcta del mismo. Su importancia estriba tanto a nivel estructural como en el papel que juegan en la caracterización de Jesús.

Estos versículos, al identificar a Jesús (personaje histórico) con el Logos encarnado y así con el Logos preexistente (personaje situado fuera de la historia), permiten al lector comprender la naturaleza del relato que va a leer: una vida antigua. Esto demuestra que la forma de contar el relato, la puesta en escena, ya forma parte del mensaje mismo y desvela, en cierto modo, la intención de la obra que el lector debe descubrir en la estructura del relato que representa el pasado y permite establecer una relación con dicho pasado ${ }^{107}$. El autor implícito quiere poner en escena a un personaje para que el lector se identifique con él y él mismo cambie su identidad o la confirme como creyente en Jesús como se pone de manifiesto en la última nota del narrador (Jn 20,30-31).

Por medio de las dos notas, el lector adquiere una posición privilegiada para leer el relato e identificar el carácter duradero de Jesús en la narración. Desde el principio conoce el verdadero origen de Jesús y el sentido de toda su misión: hacer presente la revelación definitiva de Dios por medio de sus acciones y sus palabras. A medida que recorra el relato el lector ve confirmada esta información: por sus "signos" se revelará como Mesías y manifestará su gloria y realizará la gracia y la verdad que traen la vida plena a los hombres (Jn 2,11); por sus palabras aparecerá como el Hijo, Dios Unigénito.

Equipado con estas informaciones, el lector asistirá al dramático enfrentamiento entre los judíos y Jesús y puede comprender la irónica paradoja, tan característica del relato juánico, de que los judíos rechacen a Aquel al que esperaban, al que lleva a plenitud la revelación de Moisés. Por esta razón, el lector mismo puede ponerse en guardia y no repetir los errores dramáticos de los judíos y sobre todo a entender su propia situación, rechazado y perseguido por la sinagoga $(\mathrm{Jn} 9,22)$.

107 ZuMSTEIN, “Narrativité” 324-340. 